\title{
Рослинниитво, кормовиробничтво
}

УДК 633.162:631.811

(C) 2020

\section{ВПЛИВ ПОЗАКОРЕНЕВОГО ПІДЖИВЛЕННЯ РОСЛИН ПИВОВАРНОГО ЯЧМЕНЮ НА СТРУКТУРУ КОНСИСТЕНЦІЇ ЕНДОСПЕРМУ ЗЕРНА}

\author{
O.С. Гораш ${ }^{1}$, P.I. Климишена ${ }^{2}$
}

${ }^{1}$ доктор сільськогосподарських наук

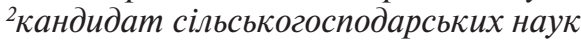

Подільський держсавний аграрно-технічний університет

вул. Шевченка, 13, м. Кам'янець-Подільський Хмельницької обл., 32300, Україна e-mail: ${ }^{1}$ GorashAS@i.ua, ${ }^{2}$ rita24@i.ua

ORCID: ${ }^{10000-0001-9418-0310 ; ~}{ }^{20000-0002-4643-7895 ~}$

Надійшла 15.11.2019

Мета. Вивчити вплив позакореневого підживлення рослин під час вегетації мікродобривами Вуксал на різних фонах мінерального удобрення на якість пивоварного ячменю ярого за параметрами консистенції ендосперму зерна. Методи. Загальнонаукові: гіпотеза, абстрагування, моделювання, спостереження, порівняння, узагальнення, конкретизація; спеціальні: польовий - для встановлення різниць між варіантами досліду, оцінка дії факторів на пивоварну якість; лабораторний - технічний аналіз для визначення консистенції ендосперму зерна ячменю; математикостатистичний - дисперсійний багаторанговий критерій Дункана для оцінки дії факторів, включених в експеримент. Результати. Показано ефективність позакореневого підживлення рослин мікродобривами Вуксал, яка полягає в стабілізації пивоварної якості вирощеного врожаю. Установлено залежність структури консистенції ендосперму зерна від технологічної схеми задіяного агрозаходу. Висновки. Максимальних результатів досягнуто за схеми 3-разового застосування позакореневого підживлення рослин ячменю мікродобривами Вуксал P Мах у фазі кущіння, Вуксал Grain у фенофазах вихід у трубку і на початку цвітіння. На фоні мінерального живлення $\mathrm{N}_{30} \boldsymbol{P}_{45} K_{45}$ за 1-разової норми 1,5 л/га отримано найменшу кількість напівскловидних зерен - 3\%, на фоні $\boldsymbol{N}_{60} \boldsymbol{P}_{90} K_{90}$ за 1-разової норми 2 л/га найменша кількість напівскловидних зерен становила 4,2\%. Дворазове застосування позакореневого підживлення рослин ячменю у фенофазах вихід у трубку і на початку цвітіння мікродобривом Вуксал Grain сприяло також поліпшенню пивоварної якості зерна. На фоні мінерального удобрення $N_{30} P_{45} K_{45}$ напівскловидних зерен було менше на 3, 5\% порівняно з контролем, 
де показник становив 4,2\%, на фоні мінерального удобрення $\mathbf{N}_{60} P_{90} K_{90}$ такого зерна було 5, 8\%, що менше на 5\%, ніж у контрольному варіанті.

Ключові слова: мінеральне удобрення, мікродобриво, скловидність, борошнистість, критерій Дункана.

DOI: https://doi.org/10.31073/agrovisnyk202001-04

Ячмінь - культура досить поширена і $\epsilon$ однією із провідних в аграрному секторі економіки. Зерно ячменю використовують на продовольчі, кормові, технічні потреби. Ячмінь $€$ незамінною сировиною для пивоварної галузі. Ще за часів стародавнього Єгипту з нього виготовляли поширений і відомий у всьому світі напій - пиво. Пріоритетність цієї культури в Україні за напрямом використання на пивоварні потреби почала змінюватися з 90-х років минулого століття, кардинально змінилися вимоги до якості зерна провідних компаній у галузі пивоваріння. Слід зазначити, що раніше особливостям технології вирощування цієї культури на потреби пивоваріння не надавалося належної уваги.

Виробництво зерна ячменю в Україні дещо скоротилося у зв'язку зі зменшенням поголів'я тварин. Проте з розширенням потужностей ПАТ «Славутський солодовий завод» та введенням в експлуатацію сучасного солодового заводу АТ «Оболонь» у смт Чемерівцях Хмельницької обл. ринок зерна пивоварного ячменю значно розширився.

Проте актуальним питанням залишається не лише збільшення обсягів виробництва зерна ячменю, а й підвищення його врожайності з поліпшеними пивоварними якостями відповідно до вимог європейських стандартів. Максимальне забезпечення потенціалу продуктивності та якості сучасних сортів ячменю $є$ пріоритетним завданням технологічного характеру. Особливо, якщо враховувати, що з підвищенням урожайності досягти кращої якості важче. Одна з причин - недостатньо приділяється уваги технологіям вирощування нових сортів [1]. Урожайність ячменю в Україні $€$ набагато нижчою порівняно з країнами ЄС, де вона становить 7 т/га [2].

Простим і важливим технологічним способом оцінки пивоварної якості зерна ячменю $€$ аналіз структури консистенції ендосперму. Метод досить практичний та ефективний, завчасно дає змогу технологу ухвалити рішення про доцільність процесу солодування відповідної партії сировини зерна ячменю. Скловидність за своєю характеристикою може бути тимчасовою і постійною. Аналіз показує, що після намочування зерна впродовж 24 год і просушування скловидної консистенції в аналізі після розтину, як правило, не спостерігається. Виділяються лише зерна напівскловидні й борошнисті. Це свідчить про так звану скловидність тимчасову, зумовлену цементацією крохмальних зерен гумі-речовинами небілкової природи. Відповідно аналіз після проведення 24-годинного зволоження зерна з дотриманням методичних рекомендацій $€$ результативно об'єктивним. Унаслідок цього значна частина тимчасово скловидних зерен стає борошнистою. Технологія солодування ячменю на початковому циклі передбачає замочування зерна. Тимчасова скловидність не впливає на пивоварну якість ячменю. Автор [3] зазначає, що така скловидність зумовлюється переважно сухою і жаркою погодою під час дозрівання і збирання урожаю. Постійна скловидність зерна свідчить про те, що ячмінь характеризується несприятливими властивостями для переробки його на солод. Такі зерна, як правило, високобілкові. Під час пророщування на солодовнях скловидність не ліквідовується, і солод із таких зерен отримують низької якості. Чим однорідніша партія за борошнистою консистенцією, тим кращим за розчинністю $є$ солод [4]. Скловидну консистенцію ендосперму зумовлюють білки, які належать до групи гістологічних. Ці групи азотистих речовин є проламінами, їх уміст у білках - 37\%. Вони розчинні лише у 80\%-му спирті, значна частина їх під час пивоваріння переходить у дробину. Неоднорідна консистенція ендосперму зумовлюється глибокими змінами його структури. Останнім часом дослідники досить часто звертають 
РОСлИНнИЦТВО, КОРМОВИРОБНИЦТВО
Вплив позакореневого підживлення рослин пивоварного ячменю на структуру консистениії ендосперму зерна увагу на якість зерна зернових культур, зокрема ячменю, пшениці [5-7].

Якість пивоварного ячменю залежить від багатьох технологічних факторів та умов середовища, включаючи особливості погоди [8-11]. Важливим технологічним фактором, що набув нині поширення, $є$ агрозахід позакореневого підживлення рослин із використанням мікродобрив для підвищення врожайності зерна і поліпшення його якості [12].

Мета досліджень - вивчити вплив позакореневого підживлення рослин під час вегетації мікродобривами Вуксал на різних фонах мінерального удобрення на якість пивоварного ячменю ярого за параметрами консистенції ендосперму зерна.

Матеріали та методи досліджень. Варіанти технологічної схеми застосування позакореневого підживлення рослин мікродобривами: 1. А0 — без підживлення рослин мікродобривом (контроль); 2. А1 - одноразове позакореневе підживлення рослин мікродобривом Вуксал Р Мах у фенофазі кущіння; 3. А2 - одноразове позакореневе підживлення рослин мікродобривом Вуксал Grain у фенофазі вихід у трубку; 4. А3 одноразове позакореневе підживлення рослин мікродобривом Вуксал Grain на початку фенофази цвітіння; 5. A4 - 2-разове позакореневе підживлення рослин мікродобривами Вуксал P Мах у фенофазі кущіння та Вуксал Grain у фенофразі вихід у трубку; 6. А5 - 2-разове позакореневе підживлення рослин мікродобривами Вуксал Р Max у фенофазі кущіння та Вуксал Grain на початку фенофази цвітіння; 7. А6 - 2-разове позакореневе підживлення рослин мікродобривами Вуксал Grain у фенофазі вихід у трубку та Вуксал Grain на початку фенофрази цвітіння; 8. A7 - 3-разове позакореневе підживлення рослин мікродобривами Вуксал P Max у френофазі кущіння, Вуксал Grain під час фенофази вихід у трубку та Вуксал Grain на початку фенофази цвітіння.

Забезпечення мінерального живлення рослин на фонах удобрення: $\mathrm{N}_{30} \mathrm{P}_{45} \mathrm{~K}_{45}-$ норма разового використання мікродобрив Вуксал 1,5 л/га та $\mathrm{N}_{60} \mathrm{P}_{90} \mathrm{~K}_{90}$ - норма разового використання мікродобрив Вуксал 2 л/га.

Об'єкт досліджень - сорт пивоварного ячменю ярого Сєбастьян.
Під час визначення консистенції ендосперму встановлювали кількість борошнистих і напівскловидних зерен. Для цього замочували зерна у воді впродовж 24 год, після чого 6 год просушували їх у звичайних умовах. Консистенцію, представлену борошнистою і напівскловидною структурами, визначали візуально через поперечний зріз зернівки. Кількість проаналізованих зерен проби - 100. Повторність - 4-разова. Математичний обрахунок даних проведено методом дисперсійного аналізу на основі критерію Дункана. 3 урахуванням доцільності та актуальності результати досліджень проаналізовано за показником умісту напівскловидних зерен.

Результати досліджень. На основі проведеного технологічного аналізу зерна доведено ефективність застосування мікродобрива під час росту і розвитку ячменю по вегетуючих рослинах щодо впливу на пивоварну якість вирощеної продукції. Результати досліджень наведено в табл. 1, де фон забезпечення мінерального живлення $\mathrm{N}_{30} \mathrm{P}_{45} \mathrm{~K}_{45}$. Найкращі показники за консистенцією структури ендосперму характеризуються найменшими значеннями кількості напівскловидних зерен або найбільшими значеннями кількості зерен борошнистої консистенції. Повністю скловидних зерен у результаті проведених аналізів по всьому досліду не виявлено.

Найкращим варіантом застосування позакореневого підживлення рослин ячменю мікродобривом у 2015 р. виявився варіант A7, де за вегетацію проведено 3 обприскування посівів робочим розчином. Відповідно найменшою була кількість зерен 3,5\%-ї напівскловидної консистенції і найбільше виявилося зерен борошнистої консистенції 96,5\%. Другим варіантом за ефективністю був варіант A6, де передбачалося застосування мікродобрива двічі за вегетацію: перший раз під час виходу в трубку, другий на початку цвітіння. Кількість скловидних зерен ячменю становила 4,2\%. Третім за ефективністю був варіант А5, коли позакореневе підживлення здійснювали під час кущіння і на початку цвітіння, показник становив 5,8\%. Слід також звернути увагу на ефективність варіанта $A 3$, де 1 раз за вегетацію задіяно позакореневе підживлення 
РОслинництво, КОРМОВИРОБНИЦТВО

мікродобривами на початку фенофази цвітіння, показник становив $6,2 \%$.

У наступному 2016 р. закономірність впливу позакореневого підживлення рослин ячменю на зазначений показник якості є такою самою. Найкраще мінімальне значення - 3\% кількості напівскловидних зерен установлено за 3-разового застосування мікродобрива. Для варіанта А6 установлено значення 4,5\%. Третій за ефективністю варіант А5 - застосування позакореневого підживлення двічі за вегетацію: під час кущіння і на початку цвітіння показник становив 5,2\%. У варіанті АЗ підживлення 1 раз за вегетацію на початку цвітіння, показник був 6\%. Різниця даних у варіантах A5 та А3 була в межах похибки.

Аналіз даних свідчить про те, що у 2017 р. установлено найменші параметри показників консистенції ендосперму за скловидністю. У варіанті A7 напівскловидних зерен було лише 2,5\%, у варіанті А6 - 3,8\%. Дещо поступається за ефективністю застосування мікродобрива варіант А5 порівняно з варіантом A6, де кількість напівскловидних зерен становила 4,8\%. Четвертий за значущістю показник $5,2 \%$ був у варіанті A3: одноразове застосування позакореневого підживлення на початку цвітіння.

Графрік на рис. 1 характеризує тренд впливу на якість зерна ячменю за загальною кількістю усіх задіяних варіантів технологічної схеми досліду. Чим менша кількість напівскловидних зерен, тим більша кількість борошнистих зерен.

За проведеним статистичним розрахунком на основі 3-річних даних за критерієм Дункана встановлено 4 статистичні окремі гомогенні групи (див. табл. 1). Найкращі результати забезпечив варіант A7 - 3-разове
Вплив позакореневого підживлення рослин пивоварного ячменю на структуру консистенції ендосперму зерна здійснення позакореневого підживлення рослин за вегетацію, виділено окрему гомогенну групу. У середньому показник кількості напівскловидних зерен становить 3\%. В окремій гомогенній групі варіант досліду А6, що свідчить про результативність 2-разового обприскування мікродобривом посівів за вегетацію у фенофазах вихід у трубку і на початку цвітіння. Середній показник за 3 роки становить $4,2 \%$. Окремо 1 статичну групу утворюють варіанти А3 та A5, що свідчить про те, що однаково впливає 1-разове застосування мікродобрива на початку цвітіння та 2-разове під час кущіння і на початку цвітіння на поліпшення технологічної якості зерна.

Аналіз даних застосування позакореневого підживлення рослин ячменю мікродобривом на фоні мінерального живлення $\mathrm{N}_{60} \mathrm{P}_{90} \mathrm{~K}_{90}$ дає підстави стверджувати про подібну закономірність впливу на консистенцію ендосперму зернівки, як і на фоні $\mathrm{N}_{30} \mathrm{P}_{45} \mathrm{~K}_{45}$. Різниця полягає у більших номінальних значеннях даних.

У 2015 р. результати змінювалися залежно від технологічної схеми застосування мікродобрива від 4,8\% до 11,5\% за кількістю зерен із напівскловидною консистенцією. Найкращі результати отримано за схеми 3-разового застосування мікродобрива за вегетацію у варіанті $A 7$, де показник становить $4,8 \%$. Істотно менші значення за 2-разового застосування мікродобрива: 1-й раз у фенофазі виходу в трубку, 2-й - на початку цвітіння. Отримані дані $-6,5 \%$ напівскловидних зерен. На 2\% більше виявилося таких зерен у варіанті А5 за 2-разового застосування мікродобрив за вегетацію порівняно з даними варіанта А6. Удвічі більше було напівскловидних зерен у варіанті
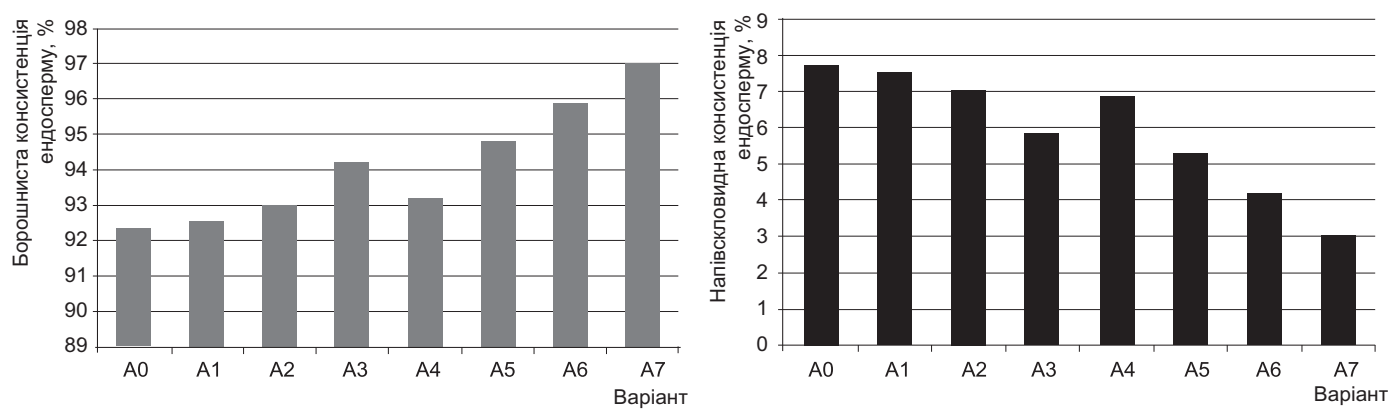

Рис. 1. Структура якості ячменю за консистенцією ендосперму зерна (фон $\left.-\boldsymbol{N}_{30} \boldsymbol{P}_{45} \boldsymbol{K}_{45}\right)$ 
1. Вплив мікродобрива на консистенцію ендосперму зерна ячменю у варіанті удобрення $N_{30} P_{45} K_{45}$ (середнє за $2015-2017$ рр.), \%

\begin{tabular}{|c|c|c|c|c|c|c|}
\hline \multirow{2}{*}{ Варіант } & \multirow{2}{*}{ Напівскловидне } & \multirow{2}{*}{ Борошнисте } & \multicolumn{4}{|c|}{ Гомогенні групи } \\
\hline & & & 1 & 2 & 3 & 4 \\
\hline 1. $\mathrm{A} 0$ & 7,7 & 92,3 & *** & - & - & - \\
\hline 2. $A 1$ & 7,5 & 92,5 & *** & - & - & - \\
\hline 3. A2 & 7,0 & 93,0 & $* * *$ & - & - & - \\
\hline 4. A4 & 6,8 & 93,2 & *** & - & - & - \\
\hline 5. A3 & 5,8 & 94,2 & - & $* * *$ & - & - \\
\hline 6. A5 & 5,2 & 94,8 & - & $* * *$ & - & - \\
\hline 7. A6 & 4,2 & 95,8 & - & - & $* * *$ & - \\
\hline 8. $A 7$ & 3,0 & 97,0 & - & - & - & *** \\
\hline
\end{tabular}

A3, де застосували мікродобрива 1 раз за вегетацію на початку цвітіння порівняно з результатами варіанта A7. Варіанти A0, A1, A2, А4 характеризуються однозначно, істотних розбіжностей даних за статистичним аналізом між ними не виявлено.

У 2016 р. кращим за впливом на технологічну якість зерна пивоварного ячменю виявився варіант A7 за 3-разового застосування мікродобрива за вегетацію. Істотно менші значення отримано у варіанті A6, де показник становить 5,8\%, різниця - 1,3\%. Відповідно 2-разове обприскування рослин ячменю у френофразі вихід у трубку і на початку цвітіння поступається за ефективністю 3-разовому застосуванню мікродобрива за вегетацію. Третій за значущістю впливу на структуру консистенції ендосперму ячменю виявився варіант А5 - 2-разове застосування мікродобрива: 1-й раз у фенофазі кущіння, 2-й — на початку цвітіння. Різниця даних порівняно з варіантом A6 - 1,2\%.
Статистично однозначний результат у варіанті A3 порівняно з варіантом A5, де різниця становить лише $0,5 \%$. Усі інші варіанти із застосуванням мікродобрива, включаючи контрольний, характеризуються більшим умістом зерен за скловидною консистенцією і меншим умістом борошнистих зерен.

У 2017 р. на 3-й рік досліджень закономірність впливу позакореневого підживлення рослин на структуру ендосперму ячменю за консистенцією характеризується аналогічно до попередніх років. Максимальну результативність забезпечив варіант A7: технологічна схема 3-разового застосування мікродобрива. Установлена кількість напівскловидних зерен - 3,5\%. У варіанті А6 напівскловидних зерен було на 1,7\% більше, ніж у варіанті A7. За впливом на якість зерна порівняно $з$ варіантами A6 і A7 поступався варіант A5 - 2-разове застосування мікродобрива у фразах кущіння і на початку цвітіння 6,5\% напівскловидних зерен від загальної
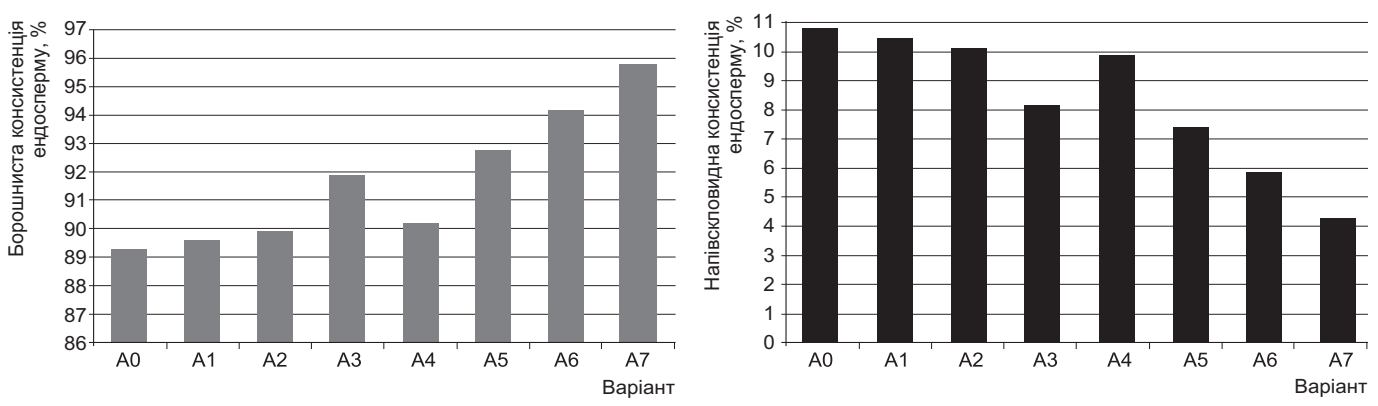

Рис. 2. Структура якості ячменю за консистенцією ендосперму зерна (фон $\left.-\boldsymbol{N}_{60} \boldsymbol{P}_{90} \boldsymbol{K}_{90}\right)$ 
2. Вплив мікродобрива на консистенцію ендосперму зерна ячменю у варіанті удобрення $\mathbf{N}_{60} P_{90} K_{90}($ середнє за $2015-2017$ рр.), \%

\begin{tabular}{|l|c|c|c|c|c|c|}
\hline \multirow{2}{*}{ Варіант } & Напівскловидне & Борошнисте & \multicolumn{3}{|c|}{ Гомогенні групи } \\
\cline { 3 - 6 } & & & 1 & 2 & 3 & 4 \\
\hline 1. A0 & 10,8 & 89,2 & $* * *$ & - & - & - \\
2. A1 & 10,4 & 89,6 & $* * *$ & - & - & - \\
3. A2 & 10,1 & *** & - & - & - \\
4. A4 & 9,8 & 89,9 & $* * *$ & - & - & - \\
5. A3 & 8,1 & 90,2 & - & $* * *$ & - \\
6. A5 & 7,3 & 91,9 & - & $* * *$ & - & - \\
7. A6 & 5,8 & 92,7 & - & - & $*$ \\
8. A7 & 4,2 & 94,2 & - & - & - \\
\hline
\end{tabular}

кількості проаналізованих. Статистичних розбіжностей у результатах варіантів A5 і АЗ не встановлено. Застосування мікродобрива у варіантах A1, A2, A4 не сприяло поліпшенню якості зерна ячменю за консистенцією структури ендосперму, значення даних були в межах 9,25-9,75\%, що істотно не відрізнялося від контролю.

Рис. 2 графрічно пояснює, що кількість борошнистих зерен залежить від кількості напівскловидних зерен за аналогією закономірності, показаної на рис. 1.

Проведений статистичний аналіз за критерієм Дункана підтверджує найкращу результативність у варіанті $A 7$, який $є$ окремою гомогенною групою (див. табл. 2).

Кількість напівскловидних зерен у середньому за 3 роки була найменшою. Другим за результативністю був варіант А6, який також виокремлювали в окрему гомогенну групу. Ефективність впливу позакореневого підживлення полягала в значній кількості борошнистих зерен - 94,2\%. Також окрему гомогенну групу утворювали разом варіанти A3 та A5, що свідчить про однозначний їх вплив на поліпшення консистенції ендосперму зерна.

Проведений порівняльний статистичний аналіз результатів за середніми даними досліду на фронах мінерального живлення $\mathrm{N}_{30} \mathrm{P}_{45} \mathrm{~K}_{45}$ та $\mathrm{N}_{60} \mathrm{P}_{90} \mathrm{~K}_{90}$ показує, що утворилося 2 окремі гомогенні групи з відповідною кількістю напівскловидних зерен - 5,9\% та 8,3\%. Це свідчить про те, що підвищення норми мінеральних добрив за вирощування ячменю пивоварного призводить до збільшення кількості зерен зі скловидною консистенцією. Показник різниці становить 2,4\%.

\section{Висновки}

Максимальних результатів досягнуто за схеми 3-разового застосування позакореневого підживлення рослин ячменю мікродобривами Вуксал Р Мах у фразі кущіння, Вуксал Grain - у френофразах виходу в трубку і на початку цвітіння. На фооні мінерального живлення $N_{30} P_{45} K_{45}$ за 1-разової норми 1,5 л/га отримано найменшу кількість напівскловидних зерен - 3\%. На фроні мінерального удобрення $\mathrm{N}_{60} P_{90} \mathrm{~K}_{90}$ за 1-разової норми 2 л/га найменша кількість напівскловидних зерен становила 4,2\%.
Дворазове застосування позакореневого підживлення рослин ячменю у фенофразах вихід у трубку і на початку цвітіння мікродобривом Вуксал Grain сприяло також поліпшенню пивоварної якості зерна. На фоні мінерального удобрення $\mathrm{N}_{30} \mathrm{P}_{45} \mathrm{~K}_{45}$ напівскловидних зерен було на 3,5\% менше, ніж на контролі, де показник становив $4,2 \%$, а на фроні мінерального удобрення $N_{60} P_{90} K_{90}$ такого зерна було 5,8\%, що на 5\% менше, ніж у контрольному варіанті. 
Horash 0. ${ }^{1}$, Klymyshena R. ${ }^{2}$

Podilsky State Agrarian Technical University, 13 Shevchenka Str., Kamianets-Podilskyi, Khmelnytskyi oblast, 32300, Ukraine; e-mail: ${ }^{1}$ GorashAS@i.ua, rita24@i.ua; ORCID: 10000-0001-9418-0310; ${ }^{2} 0000-$ 0002-4643-7895

Effect of a foliar top dressing of plants of malting barley on the structure of consistence of endosperm of the grain

Goal. To study the effect of a foliar top dressing of plants during the growing season with micronutrient «Vuksal» (on different backgrounds of mineral fertilizer) on malting quality of spring barley in the parameters of consistency of endosperm of the grain. Methods. Scientific: hypothesis, abstraction, modeling, observation, comparison, generalization, concretization; special: field - to establish the differences between the variants of experience, assessment of action factors on malting quality; laboratory - technical analysis to determine the consistency of the endosperm of barley grain; mathematical and statistical — dispersion multi-rank Duncan criterion for assessment of the factors included in the experiment. Results. The effectiveness is shown of a foliar top dressing of plants with micronutrient «Vuksal». It stabilizes the malting quality of the harvest. The dependence is fixed of the structure consistency of the endosperm of the grain on the technological scheme of the used agricultural measures. Conclusions. Maximum results were achieved at the use of the scheme with a 3-time foliar top dressing of plants of barley with micronutrient "Vuksal R Max» in the phase of tillering, «Vuksal Grain» in the phenological stages of stem elongation and early flowering. On the background of mineral nutrition with $\mathrm{N}_{30} \mathrm{P}_{45} \mathrm{~K}_{45}$ (1-time dose $1.5 \mathrm{I} /$ hectare), they obtained the least amount of half- vitreous grains $-3 \%$. On the background of mineral nutrition with N60P90K90 (1-time dose $2 \mathrm{l} /$ hectare), the least amount of half- vitreous grains was $4.2 \%$. The double application of foliar top dressing of barley plants in the phenological stages of stem elongation and early flowering with micronutrient «Vuksal Grain» also contributed to the improvement of malting quality of grain. On the background of mineral nutrition with $\mathrm{N}_{30} \mathrm{P}_{45} \mathrm{~K}_{45}$, the amount of half-vitreous grains was less than $3.5 \%$ as compared to the control, where the rate was $4.2 \%$. On the background of mineral nutrition with $\mathrm{N}_{60} \mathrm{P}_{90} \mathrm{~K}_{90}$, the amount of such grain was $5.8 \%$, and $5 \%$ less than in the control variant.

Key words: fertilizer, micronutrient fertilizers, vitreousness, mealiness, Duncan criterion..

DOI: https://doi.org/10.31073/agrovisnyk202001-04

\section{Бібліографія}

1. Демидов О., Гудзенко В. Ячмінь ярий: реалізація потенціалу продуктивності. Пропозиція. 2017. № 2. C. 66-69.

2. Piedra-Munoz L., Galdeano-Gomez E., PerezMesa J.C. Is Sustainability Compatible with Profitability? An Empirical Analysis on Family Farming Activity. Sustainability. 2016. V. 8 (9). P. 893. doi: 10.3390/su8090893

3. Романюк B.І. Формування високопродуктивних посівів ячменю ярого залежно від факторів інтенсифікації в умовах Лісостепу Правобережного. Вісник аграрної науки. 2018. № 9 (786). C. 79-84. doi: 10.31073/agrovisnyk201809-12

4. Нарцисс Л. Пивоварение. Т. 1. Технология солодоращения; пер. с нем.; под. ред. Г.А. Ермолаевой, Е.Ф. Шаненко. Санкт-Петербург: Профрессия, 2007. 584 с.

5. Петриченко В.Ф., Романюк В.І. Вплив факторів інтенсифікації на якість зерна ячменю ярого в умовах Лісостепу Правобережного. Таврійський науковий вісник. 2019. № 105. C. $127-134$.

6. Чернобай С.В. Формування показників якості зерна ячменю ярого за впливу норми висіву та позакореневих підживлень. Вісник аграрної науки Причорномор'я. 2014. Вип. 4. С. 163-169.

7. Лопушняк B.І., Вега Н.I. Залежність рівня продуктивності ячменю ярого від норм внесення мінеральних добрив та позакореневих підживлень в умовах західного Лісостепу. Вісник Сумського національного аграрного університету. Серія «Агрономія і біологія». 2015. Вип. 3(29). C. 113-115.

8. Гораш О.С. Управління продуційним процесом пивоварного ячменю: монографія; вид. 2 з доп. Кам'янець-Подільський: ПП «Медобори2006», 2017. 464 c.

9. Genc Y., McDonald G.K., Graham R.D. Critical deficiency concentration of zinc in barley genotypes differing in zinc efficiency and its relation to growth responses. J. Plant Nutr. 2002. 25. № 3. P. 545-560. doi: $10.1081 /$ pln-120003381

10. Kenbaev B., Sade B. Response of fieldgrown barley cultivars grown on zinc-deficient soil to zinc application. Commun. Soil Sci. and Plant Anal. 2002. 33. № 3-4. P. 533-544. doi: 10.1081/ css-120002762

11. Maleki Farahani S., Chaichi M.R., Mazaheri $D$. et al. Barley Grain Mineral Analysis as Affected by Different Fertilizing Systems and by Drought Stress. J. Agr. Sci. Tech. 2011. V. 13. P. 315-326.

12. Маслійов С.В., Беседа О.О., Гончаренко А.О. Вплив мікродобрив та окремих елементів технології вирощування на формування якісних показників озимої пшениці. Таврійський науковий вісник. 2018. № 104. С. 64-70. 